\title{
Metabolic Profile and Evaluation of Biological Activities of Extracts from the Stems of Cissus trifoliata
}

\author{
Luis Fernando Méndez-López ${ }^{1}$, Elvira Garza-González ${ }^{2}$, María Yolanda Ríos ${ }^{3}{ }^{\mathbb{D}}$, \\ M. Ángeles Ramírez-Cisneros ${ }^{3}$, Laura Alvarez ${ }^{3}{ }^{(0)}$, Leticia González-Maya ${ }^{4}$ (i), \\ Jessica N. Sánchez-Carranza ${ }^{4}$ and María del Rayo Camacho-Corona ${ }^{1, *(\mathbb{D})}$ \\ 1 Facultad de Ciencias Químicas, Universidad Autónoma de Nuevo León, Av. Universidad S/N Ciudad \\ Universitaria, San Nicolás de los Garza C.P. 66451, Nuevo León, Mexico; luis.mendezl@uanl.mx \\ 2 Servicio de Gastroenterología Hospital Universitario Dr. José Eleuterio González, Universidad Autónoma de \\ Nuevo León, Av. Gonzalitos y Madero S/N, Col. Mitras Centro, Monterrey C.P. 64460, Nuevo León, Mexico; \\ elvira_garza_gzz@yahoo.com \\ 3 Centro de Investigaciones Químicas IICBA, Universidad Autónoma del Estado de Morelos, Av. Universidad \\ 1001, Col. Chamilpa, Cuernavaca C.P. 62209, Morelos, Mexico; myolanda@uaem.mx (M.Y.R.); \\ angelesrc@uaem.mx (M.Á.R.-C.); lalvarez@uaem.mx (L.A.) \\ 4 Facultad de Farmacia, Universidad Autónoma del Estado de Morelos, Av. Universidad 1001, Col. Chamilpa, \\ Cuernavaca C.P. 62209, Morelos, Mexico; letymaya@uaem.mx (L.G.-M.); jez_chazaq@hotmail.com (J.N.S.-C.) \\ * Correspondence: maria.camachocn@uanl.edu.mx; Tel.: +52-81-8329-4000-3414
}

Received: 10 January 2020; Accepted: 29 January 2020; Published: 31 January 2020

\begin{abstract}
Cissus trifoliata (L.) L belongs to the Vitaceae family and is an important medicinal plant used in Mexico for the management of infectious diseases and tumors. The present study aimed to evaluate the metabolic profile of the stems of $C$. trifoliata and to correlate the results with their antibacterial and cytotoxic activities. The hexane extract was analyzed using gas chromatography coupled with mass spectrometry (GC-MS) and the $\mathrm{CHCl}_{3}-\mathrm{MeOH}$ and aqueous extracts by ultraperformance liquid chromatography quadrupole time of fly mass spectrometry (UPLC-QTOF-MS). The antibacterial activity was determined by broth microdilution and the cytotoxicity was evaluated using MTS cell proliferation assay. Forty-six metabolites were putatively identified from the three extracts. Overall, terpenes, flavonoids and stilbenes characterize the metabolic profile. No antibacterial activity was found in any extract against the fifteen bacteria strains tested (MIC $>500 \mu \mathrm{g} / \mathrm{mL}$ ). However, high cytotoxic activity $\left(\mathrm{IC}_{50} \leq 30 \mu \mathrm{g} / \mathrm{mL}\right)$ was found in the hexane and aqueous extracts against hepatocarcinoma and breast cancer cells (Hep3B, HepG2 and MCF7). This is the first report of the bioactive compounds of $C$. trifoliata stems and their antibacterial and cytotoxic properties. The metabolic profile rich in anticancer compounds correlate with the cytotoxic activity of the extracts from the stems of $C$. trifoliata. This study shows the antitumor effects of this plant used in the traditional medicine and justifies further research of its anticancer activity.
\end{abstract}

Keywords: Hierba del buey; anticancer; GC-MS; LC-MS; bioactive compounds

\section{Introduction}

Plants from the genus Cissus have been used globally in traditional medicine for the treatment of several diseases such as arthritis, obesity, cancer, infections and diabetes [1]. Cissus plants have shown a wide spectrum of medicinal properties, including anti-microbial [2], anti-inflammatory [3], anti-tumor [4], and anti-diabetic [5]. Cissus species produce a wealth of phytochemicals, including triterpenes, fatty acids, glycerolipids, steroids, phytols, cerebrosides, flavonoids and 
stilbenes [6,7]. The full bioactive compounds of these plants have yet to be elucidated, but among the bioactive phytochemicals isolated from Cissus plants are $\beta$-sitosterol, stigmasterol, ursolic acid, kaempferol, quercetin, resveratrol, and lupeol [8,9]. Cissus trifoliata (L.) L, also known as "Hierba del buey", is a plant widely distributed in Mexico, Southern United States and the Caribbean South America. In Mexican traditional medicine, a decoction of its stems is applied to the affected site or used as infusion for the management of gastrointestinal illnesses [10] and tumors [11]. To our knowledge, there are no previous chemical studies of $C$. trifoliata or its antibacterial and cytotoxic activities. Currently, only one study has been carried out concerning the anti-inflammatory activity of extracts using murine models [12]. However, in vitro antibacterial activity of stem extracts from C. quadrangularis [13] and C. pallida [14] has been reported against Bacillus subtilis, Klebsiella pneumoniae, Staphylococcus aureus, Escherichia coli, Salmonella typhi, Bacillus cereus and Pseudomonas aeruginosa. On the other hand, cytotoxic effects of the stem extracts of C. quadrangularis [15], C. verticillate [16], C. sicyoides [17], and C. debilis [18] have been shown against HeLa, A431, HepG2 and CaCo-2 cells. Therefore, the ethnomedical knowledge and the chemotaxonomic relationship of $C$. trifoliata suggest that their stems might be a good source of bioactive compounds.

Metabolic profiling has been previously useful to understand the chemical diversity of a medicinal plant. This information can be used to compare it with taxonomically related studied plants and to infer their bioactivity [19-21]. Chromatography coupled to mass spectrometry is the most widely applied technology used for the analysis of samples in very complex matrices such as those of plant extracts [22]. The aim of this study was to investigate the metabolic profile of the hexane, $\mathrm{CHCl}_{3}-\mathrm{MeOH}$ and aqueous extracts of $C$. trifoliata stems by a GC-MS and Ultraperformance Liquid Chromatography-Quadrupole Time of Fly-Mass Spectrometry (UPLC-QTOF-MS) analysis. For their profiling, a database of reported compounds of the plants of the genus was established and used in conjunction with the available libraries. Based on high-mass accuracy, spectral data and previous reports, a tentatively compound identification was assigned. In order to shed more light on the medicinal use of $C$. trifoliata, the antibacterial and the cytotoxic activity were evaluated by microdilution and MTS assays. Additionally, the potential mechanism of action of the extracts was discussed according to their bioactive compound content.

\section{Results}

\subsection{GC-MS Analysis of Hexane Stem Extract of C. trifoliata}

The volatile contents of hexane stem extract of $C$. trifoliata were analyzed by GC-MS. The chromatogram is showed in Figure 1. The identification of the components was based on the comparison of their GC-MS spectra and Kovats retention index with referent compounds in the NIST library [23] (Table 1). The hexane extract contained sixteen compounds belonging to the chemical classes of alkanes $(18.7 \%)$, fatty acids (31.3\%), terpenes $(37.5 \%)$, alcohols $(6.25 \%)$ and esters $(6.25 \%)$.

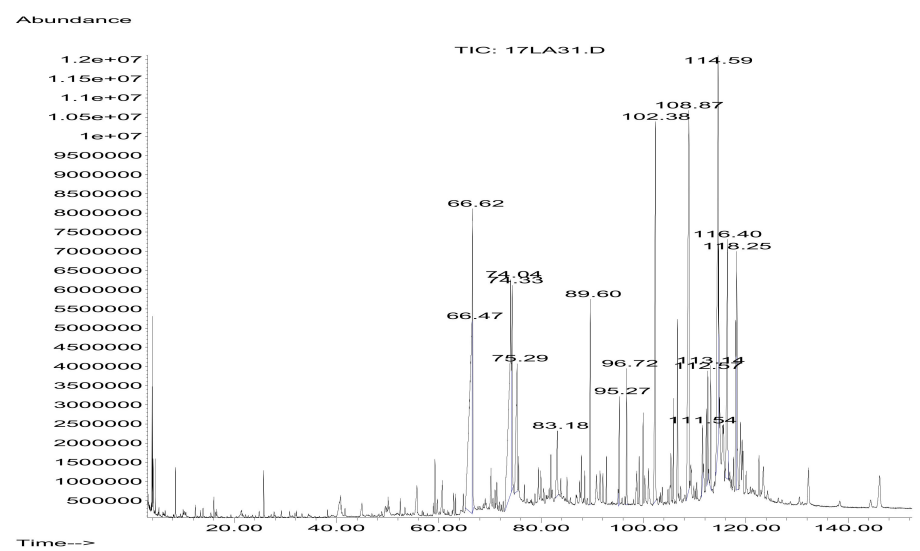

Figure 1. GC-MS chromatogram of hexane stem extract of C. trifoliata. 
Table 1. GC-MS analysis of hexane stems extract of $C$. trifoliata.

\begin{tabular}{|c|c|c|c|c|c|c|}
\hline RT (min) & Abundance (\%) & $\begin{array}{l}\text { Molecular } \\
\text { Weight }\end{array}$ & $\begin{array}{l}\text { Molecular } \\
\text { Formula }\end{array}$ & Tentatively Identified Compound & $\begin{array}{l}\text { Retention } \\
\text { Index }\end{array}$ & $\begin{array}{c}\text { Metabolite } \\
\text { Class }\end{array}$ \\
\hline 66.472 & 14.39 & 256.4241 & $\mathrm{C}_{16} \mathrm{H}_{32} \mathrm{O}_{2}$ & Hexadecanoic acid & 1964 & Fatty acid \\
\hline 66.623 & 5.35 & 284.4772 & $\mathrm{C}_{18} \mathrm{H}_{36} \mathrm{O}_{2}$ & Hexadecanoic acid ethyl ester & 1994 & Fatty ester \\
\hline 74.039 & 12.60 & 280.4455 & $\mathrm{C}_{18} \mathrm{H}_{32} \mathrm{O}_{2}$ & 9Z,12Z-Octadecadienoic acid & 1977 & Fatty acid \\
\hline 74.328 & 4.63 & 282.4614 & $\mathrm{C}_{18} \mathrm{H}_{34} \mathrm{O}_{2}$ & 9Z-Octadecenoic acid & 2140 & Fatty acid \\
\hline 75.294 & 4.42 & 284.4772 & $\mathrm{C}_{18} \mathrm{H}_{36} \mathrm{O}_{2}$ & Octadecanoic acid & 2188 & Fatty acid \\
\hline 83.176 & 2.01 & 312.5304 & $\mathrm{C}_{20} \mathrm{H}_{40} \mathrm{O}_{2}$ & Eicosanoic acid & 2366 & Fatty acid \\
\hline 89.609 & 1.94 & 394.7601 & $\mathrm{C}_{28} \mathrm{H}_{58}$ & Octacosane & 2800 & Alkane \\
\hline 95.271 & 3.15 & 410.7180 & $\mathrm{C}_{30} \mathrm{H}_{50}$ & Squalene & 2847 & Triterpene \\
\hline 102.377 & 10.45 & 408.7867 & $\mathrm{C}_{29} \mathrm{H}_{60}$ & Nonacosane & 2900 & Alkane \\
\hline 108.871 & 12.82 & 436.8399 & $\mathrm{C}_{31} \mathrm{H}_{64}$ & Hentriacontane & 3100 & Alkane \\
\hline 111.546 & 1.81 & 400.6801 & $\mathrm{C}_{28} \mathrm{H}_{48} \mathrm{O}$ & Campesterol & 3131 & Sterol \\
\hline 112.571 & 1.91 & 412.6908 & $\mathrm{C}_{29} \mathrm{H}_{48} \mathrm{O}$ & Stigmasterol & 3170 & Sterol \\
\hline 113.143 & 1.73 & 454.4749 & $\mathrm{C}_{30} \mathrm{H}_{62} \mathrm{O}_{2}$ & 1,30-Triacontanediol & 3241 & Alcohol \\
\hline 114.588 & 11.23 & 414.7067 & $\mathrm{C}_{29} \mathrm{H}_{50} \mathrm{O}$ & $\beta$-sitosterol & 3187 & Sterol \\
\hline 116.401 & 6.53 & 426.7174 & $\mathrm{C}_{30} \mathrm{H}_{50} \mathrm{O}$ & Lupeol & 3320 & Triterpene \\
\hline 118.246 & 5.03 & 412.6908 & $\mathrm{C}_{29} \mathrm{H}_{48} \mathrm{O}$ & Stigmast-4-en-3-one & 3435 & Ketone \\
\hline
\end{tabular}

\subsection{UPLC-QTOF-MS Analysis of $\mathrm{CHCl}_{3}-\mathrm{MeOH}$ Stems Extract of C. trifoliata}

The chromatogram of the UPLC-QTOF-MS analysis of $\mathrm{CHCl}_{3}-\mathrm{MeOH}$ stem extract of $\mathrm{C}$. trifoliata is shown in Figure 2. Eighteen compounds were tentatively identified based on accurate $m / z$ and the molecular formula [24] (Table 2). These included simple phenolics (16.6\%), fatty acids (22.2\%), flavonoids (44.6\%), and stilbenes (16.6\%).

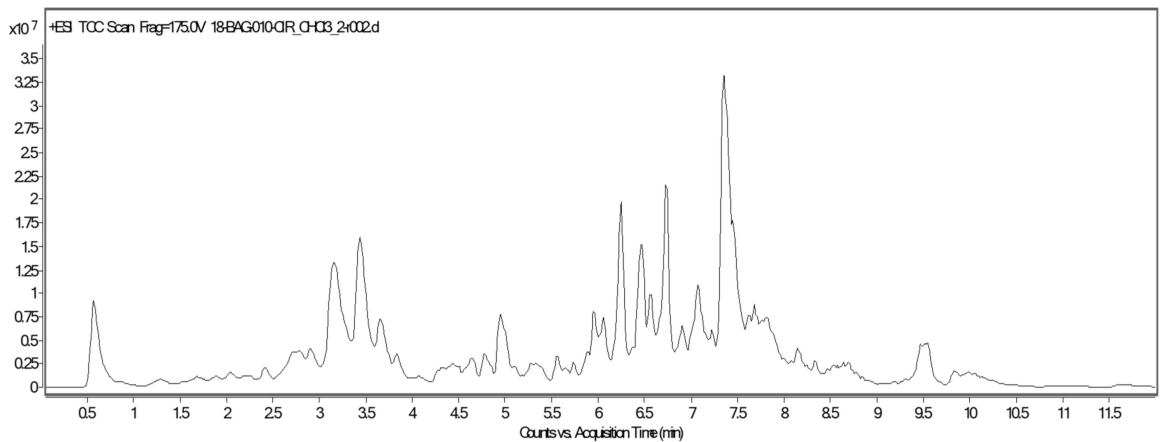

Figure 2. Chromatogram of UPLC-QTOF-MS analysis of $\mathrm{CHCl}_{3}-\mathrm{MeOH}$ stems extract of $\mathrm{C}$. trifoliata.

Table 2. UPLC-QTOF-MS analysis of $\mathrm{CHCl}_{3}-\mathrm{MeOH}$ stems extract of $\mathrm{C}$. trifoliata.

\begin{tabular}{|c|c|c|c|c|c|c|}
\hline RT (min) & $\begin{array}{l}\text { Experimental } \\
m / z\left[^{-} \mathrm{M}-\mathrm{H}\right]^{-}\end{array}$ & $\begin{array}{l}\text { Theoretical } \\
\text { Mass }\end{array}$ & $\begin{array}{l}\text { Mass Error } \\
\text { (ppm) }\end{array}$ & $\begin{array}{l}\text { Molecular } \\
\text { Formula }\end{array}$ & Tentatively Identified Compound & $\begin{array}{c}\text { Metabolite } \\
\text { Class }\end{array}$ \\
\hline 0.612 & 593.1497 & 594.1590 & 1.69 & $\mathrm{C}_{27} \mathrm{H}_{30} \mathrm{O}_{15}$ & Kaempferol-O- $\alpha$-rhamnosyl-glucopyranoside & Flavonoid \\
\hline 2.419 & 625.1436 & 626.1488 & 1.60 & $\mathrm{C}_{27} \mathrm{H}_{30} \mathrm{O}_{17}$ & Myricetin 3-O-rutinoside & Flavonoid \\
\hline 2.857 & 507.1147 & 508.1222 & 1.98 & $\mathrm{C}_{23} \mathrm{H}_{24} \mathrm{O}_{13}$ & Syringetin 3-O-galactoside & Flavonoid \\
\hline 3.226 & 405.1198 & 406.1269 & 2.47 & $\mathrm{C}_{20} \mathrm{H}_{22} \mathrm{O}_{9}$ & Piceatannol glucoside & Stilbene \\
\hline 3.547 & 595.1341 & 596.1382 & 1.68 & $\mathrm{C}_{26} \mathrm{H}_{28} \mathrm{O}_{16}$ & Quercetin 3-O-glucosyl-xyloside & Flavonoid \\
\hline 3.774 & 310.2052 & - & - & -20 & Unknown & - \\
\hline 4.042 & 315.0717 & 316.0799 & 3.18 & $\mathrm{C}_{13} \mathrm{H}_{16} \mathrm{O}_{9}$ & Protocatechuic acid hexoside & Phenolic \\
\hline 4.807 & 433.1140 & 434.1218 & 2.32 & $\mathrm{C}_{21} \mathrm{H}_{22} \mathrm{O}_{10}$ & Dihydrokaempferol 3-O-rhamnoside & Flavonoid \\
\hline 5.090 & 389.1249 & 390.1320 & 2.58 & $\mathrm{C}_{20} \mathrm{H}_{22} \mathrm{O}_{8}$ & Resveratrol 3-O-glucoside & Stilbene \\
\hline 5.813 & 473.0362 & 474.0439 & 2.12 & $\mathrm{C}_{21} \mathrm{H}_{14} \mathrm{O}_{13}$ & Trigallic acid & Phenolic \\
\hline 5.895 & 431.0939 & - & - & $-21+10$ & Unknown & - \\
\hline 6.180 & 335.0403 & 336.0486 & 3.00 & $\mathrm{C}_{15} \mathrm{H}_{12} \mathrm{O}_{9}$ & Methyl digallate & Phenolic \\
\hline 6.423 & 433.0760 & 434.0854 & 2.32 & $\mathrm{C}_{20} \mathrm{H}_{18} \mathrm{O}_{11}$ & Quercetin arabinoside & Flavonoid \\
\hline 6.531 & 336.1840 & - & - & - & Unknown & - \\
\hline 6.592 & 615.1869 & 616.1950 & 1.63 & $\mathrm{C}_{34} \mathrm{H}_{32} \mathrm{O}_{11}$ & Pallidol-3-O-glucoside & Stilbene \\
\hline 6.763 & 447.0938 & 448.1011 & 2.24 & $\mathrm{C}_{21} \mathrm{H}_{20} \mathrm{O}_{11}$ & Kaempferol 3-O-galactoside & Flavonoid \\
\hline 7.169 & 615.0988 & 616.1069 & 1.63 & $\mathrm{C}_{28} \mathrm{H}_{24} \mathrm{O}_{16}$ & Myricitrin O-gallate & Flavonoid \\
\hline 7.191 & 297.3810 & - & - & - & Unknown & - \\
\hline 7.417 & 253.2161 & 254.2251 & 3.96 & $\mathrm{C}_{16} \mathrm{H}_{30} \mathrm{O}_{2}$ & Hexadecenoic acid & Fatty acid \\
\hline 7.534 & 279.2348 & 280.2407 & 3.58 & $\mathrm{C}_{18} \mathrm{H}_{32} \mathrm{O}_{2}$ & Octadecadienoic acid & Fatty acid \\
\hline 7.595 & 255.2345 & 256.2407 & 3.92 & $\mathrm{C}_{16} \mathrm{H}_{32} \mathrm{O}_{2}$ & Palmitic acid & Fatty acid \\
\hline 7.852 & 283.2649 & 284.2720 & 3.54 & $\mathrm{C}_{18} \mathrm{H}_{36} \mathrm{O}_{2}$ & Stearic acid & Fatty acid \\
\hline 8.272 & 653.2235 & - & - & - & Unknown & - \\
\hline 9.480 & 535.1650 & - & - & - & Unknown & - \\
\hline
\end{tabular}




\subsection{UPLC-QTOF-MS Analysis of Aqueous Stems Extract of C. trifoliata}

The chromatogram of UPLC-QTOF-MS analysis of aqueous stem extract of $C$. trifoliata is shown in Figure 3. Twelve compounds were tentatively identified based on accurate $\mathrm{m} / \mathrm{z}$ and the molecular formula [24] (Table 3). These include flavonoids (83\%) and stilbenes (17\%).

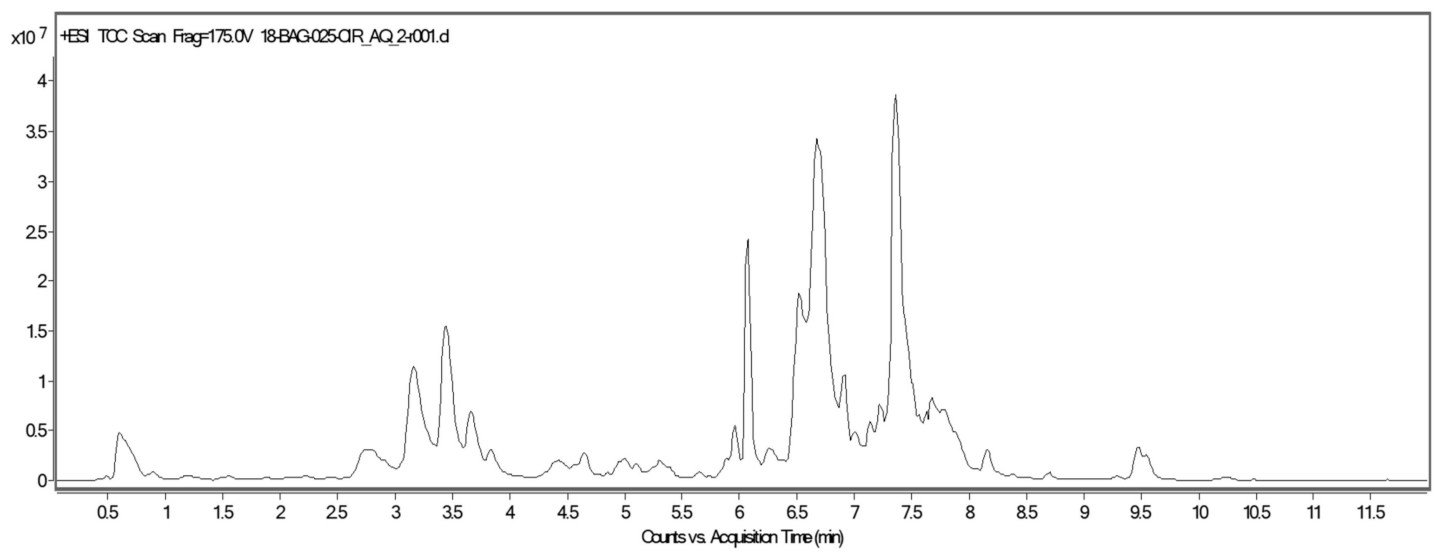

Figure 3. Chromatogram of UPLC-QTOF-MS analysis of aqueous stems extract of C. trifoliata.

Table 3. UPLC-QTOF-MS analysis of aqueous stems extract of C. trifoliata.

\begin{tabular}{|c|c|c|c|c|c|c|}
\hline RT (min) & $\begin{array}{c}\text { Experimental } \\
m / z \text { [M-H }^{-}\end{array}$ & $\begin{array}{c}\text { Theoretical } \\
\text { Mass }\end{array}$ & $\begin{array}{l}\text { Mass Error } \\
\text { (ppm) }\end{array}$ & $\begin{array}{l}\text { Molecular } \\
\text { Formula }\end{array}$ & Tentatively Identified Compound & $\begin{array}{c}\text { Metabolite } \\
\text { Class }\end{array}$ \\
\hline 0.612 & 592.9786 & 594.1590 & 1.98 & $\mathrm{C}_{27} \mathrm{H}_{30} \mathrm{O}_{15}$ & Apigenin-6,8-di-C- glycoside & Flavonoid \\
\hline 2.781 & 563.0218 & 564.1484 & 1.99 & $\mathrm{C}_{26} \mathrm{H}_{28} \mathrm{O}_{14}$ & Kaempferol rhamnosyl xyloside & Flavonoid \\
\hline 3.180 & 405.1198 & 406.1269 & 2.47 & $\mathrm{C}_{20} \mathrm{H}_{22} \mathrm{O}_{9}$ & Piceatannol glucoside & Stilbene \\
\hline 3.497 & 595.1341 & 596.1382 & 1.68 & $\mathrm{C}_{26} \mathrm{H}_{28} \mathrm{O}_{16}$ & Quercetin 3-O-glucosyl-xyloside & Flavonoid \\
\hline 3.689 & 609.1451 & 610.1539 & 1.65 & $\mathrm{C}_{27} \mathrm{H}_{30} \mathrm{O}_{16}$ & Kaempferol 3,7-O-diglucoside & Flavonoid \\
\hline 4.457 & 374.4914 & - & - & - & Unknown & - \\
\hline 4.665 & 593.1497 & 594.1590 & 1.69 & $\mathrm{C}_{27} \mathrm{H}_{30} \mathrm{O}_{15}$ & Kaempferol-O- $\alpha$-rhamnosyl-glucopyranoside & Flavonoid \\
\hline 5.078 & 453.1356 & 454.1421 & 2.21 & $\mathrm{C}_{28} \mathrm{H}_{22} \mathrm{O}_{6}$ & E-Viniferin & Stilbene \\
\hline 5.395 & 400.3705 & - & - & -20 & Unknown & - \\
\hline 5.973 & 755.2030 & 756.2118 & 1.33 & $\mathrm{C}_{33} \mathrm{H}_{40} \mathrm{O}_{20}$ & Kaempferol 3-O-glucosyl-rhamnosyl-galactoside & Flavonoid \\
\hline 6.179 & 594.1627 & - & - & - & Unknown & - \\
\hline 6.423 & 433.0760 & 434.0854 & 2.32 & $\mathrm{C}_{20} \mathrm{H}_{18} \mathrm{O}_{11}$ & Quercetin arabinoside & Flavonoid \\
\hline 6.779 & 448.1011 & 449.1089 & 2.24 & $\mathrm{C}_{21} \mathrm{H}_{21} \mathrm{O}_{11}$ & Cyanidin 3-O-galactoside & Flavonoid \\
\hline 6.954 & 464.0960 & 465.1038 & 2.16 & $\mathrm{C}_{21} \mathrm{H}_{21} \mathrm{O}_{12}$ & Delphinidin 3-O-glucoside & Flavonoid \\
\hline 7. 384 & 447.0930 & 448.1011 & 2.24 & $\mathrm{C}_{21} \mathrm{H}_{20} \mathrm{O}_{11}$ & Kaempferol hexoside & Flavonoid \\
\hline 7.465 & 576.4380 & - & - & - & Unknown & - \\
\hline 7.645 & 302.0060 & - & - & - & Unknown & - \\
\hline 7.851 & 426.7290 & - & - & - & Unknown & - \\
\hline
\end{tabular}

\subsection{Biological Evaluation of C. trifoliata Stem Extracts}

\subsubsection{Antibacterial Activity}

Extracts were evaluated for their activity against fifteen bacteria, including sensitive and antibiotic-resistant strains. The antibacterial activity of the three $C$. trifoliata stem extracts was null against all the bacteria at the concentrations tested (500, 250, 125, 62.5, 31.2, 15.6 and $7.8 \mu \mathrm{g} / \mathrm{mL}$ ). According to recommendations, plant extracts should exhibit antibacterial activity at MICs $\leq$ $30 \mu \mathrm{g} / \mathrm{mL}$ [25]. On the other hand, sensitivity to the positive control levofloxacin differs among the tested strains and showed inhibitory concentrations in the range of 3.12 to $50.0 \mu \mathrm{g} / \mathrm{mL}$ (Table 4).

\subsubsection{Cytotoxic Activity}

The potential cytotoxic activity of $C$. trifoliata stem extracts was evaluated against six cancer cell lines: liver cancer (HepG2, Hep3B), breast cancer (MCF7), prostate cancer (PC3), cervix cancer (HeLa), and lung cancer (A549), that were selected because they represent the most studied cell models of the most common cancer types diagnosed in the Mexican population. Cancer cells were treated with extracts at concentrations of 100,10,1, $0.1,0.001 \mu \mathrm{g} / \mathrm{mL}$ for a dose-response evaluation with an exposition of $72 \mathrm{~h}$ according to the literature [26]. The half maximal inhibitory concentration $\left(\mathrm{IC}_{50}\right)$ 
was calculated for extracts and paclitaxel using MTS assays (Table 5). According to the criteria of the National Cancer Institute (NCI), extracts with $\mathrm{IC}_{50} \leq 30 \mu \mathrm{g} / \mathrm{mL}$ should be considered cytotoxic [26]. Therefore, the results indicate that liver and breast cancer cells were more sensitive to the hexane extract and that breast cancer cells were more affected by the aqueous extract.

Table 4. Activity of the extracts of Cissus trifoliata stems and levofloxacin against bacteria $(\mu \mathrm{g} / \mathrm{mL})$.

\begin{tabular}{ccccc}
\hline Bacteria & Hexane & $\mathbf{C H C l}_{\mathbf{3}}$-MeOH & Aqueous & Levofloxacin \\
\hline S. aureus (ATCC, 29213) & $\geq 500$ & $\geq 500$ & $\geq 500$ & 3.12 \\
S. epidermidis (ATCC, 14990) & $\geq 500$ & $\geq 500$ & $\geq 500$ & 3.12 \\
E. faecium (ATCC, 2127) & $\geq 500$ & $\geq 500$ & $\geq 500$ & 3.12 \\
E. coli (ATCC, 25922) & $\geq 500$ & $\geq 500$ & $\geq 500$ & 3.12 \\
P. aeruginosa (ATCC, 27853) & $\geq 500$ & $\geq 500$ & $\geq 500$ & 3.12 \\
K. pneumoniae (ATCC, 19606) & $\geq 500$ & $\geq 500$ & $\geq 500$ & 3.12 \\
A. baumanni (ATCC, 13883) & $\geq 500$ & $\geq 500$ & $\geq 500$ & 3.12 \\
Methicillin-resistant S.aureus (14-2095) & $\geq 500$ & $\geq 500$ & $\geq 500$ & 12.5 \\
Linezolid-resistant S. epidermidis (14-583) & $\geq 500$ & $\geq 500$ & $\geq 500$ & 6.25 \\
Vancomycin-resistant E. faecium (10-984) & $\geq 500$ & $\geq 500$ & $\geq 500$ & 12.5 \\
ESBL- resistant E.coli (14-2081) & $\geq 500$ & $\geq 500$ & $\geq 500$ & 25.0 \\
Carbapenem-resistant P. aeruginosa (13-1391) & $\geq 500$ & $\geq 500$ & $\geq 500$ & 12.5 \\
Oxacillin-resistant K. pneumoniae (17-1692) & $\geq 500$ & $\geq 500$ & $\geq 500$ & 6.25 \\
NDM-1+- resistant K. pneumoniae (14-3335) & $\geq 500$ & $\geq 500$ & $\geq 500$ & 50.0 \\
Carbapenem-resistant A. baumannii (12-666) & $\geq 500$ & $\geq 500$ & $\geq 500$ & 12.5 \\
\hline
\end{tabular}

ESBL: Extended spectrum $\beta$-lactamase; NDM-1+: New Delhi metallo- $\beta$-lactamase.

Table 5. Activity of $C$. trifoliata stem extracts against cancer cell lines.

\begin{tabular}{ccccc}
\hline Cell line & Hexane & $\mathbf{C H C l}_{3}$-MeOH & Aqueous & Paclitaxel \\
\hline HepG2 & $26 \pm 2$ & $80 \pm 8$ & $79 \pm 5$ & $64.0 \times 10^{-3}$ \\
Hep3B & $24 \pm 2$ & $81 \pm 4$ & $81 \pm 7$ & $33.0 \times 10^{-3}$ \\
MCF7 & $30 \pm 3$ & $78 \pm 5$ & $30 \pm 2$ & $5.12 \times 10^{-3}$ \\
HeLa & $35 \pm 3$ & $82 \pm 4$ & $90 \pm 8$ & $5.12 \times 10^{-3}$ \\
A549 & $51 \pm 4$ & $85 \pm 3$ & $94 \pm 6$ & $4.27 \times 10^{-3}$ \\
PC3 & $62 \pm 3$ & $61 \pm 3$ & $58 \pm 4$ & $79.4 \times 10^{-3}$ \\
\hline
\end{tabular}

The $\mathrm{IC}_{50} \mu \mathrm{g} / \mathrm{mL}$ was determined by MTS and is showed as mean $\pm \mathrm{SD}$.

\section{Discussion}

\subsection{Metabolic Profile of Stems Extracts from C. trifoliata}

Metabolic profiling of plant extracts refers to the analysis by hyphenated techniques such as GC-MS and LC-MS [27]. Accurate mass spectrometry and spectral data are then processing with specific algorithms which provide a specific molecular formula and then the metabolites are identified in available databases [24]. Following this approach, forty-six metabolites were identified. The metabolic profiles of extracts from the stems of C. trifoliata included alcohols, alkanes, esters, fatty acids, terpenes and phenolic compounds. Overall, the compounds identified in the hexane extract are common constituents of cuticles and membranes of most plants [28,29]. The medicinal plant from the genus with most chemical and pharmacological studies is C. quadrangularis. The palmitic, stearic, linoleic and oleic fatty acids have been previously identified from its hexane stem extracts [30,31]. The terpenes squalene, beta sitosterol, campesterol, stigmasterol and lupeol have also been previously reported in the hexane and methanol extracts from the stems of C. quadrangularis [6,30,32].

On the other hand, most of the compounds identified by LC-MS were polyphenols. Flavonoids were the main chemical class identified, and kaempferol and quercetin glucosides account for most of them. Apigenin, kaempferol and quercetin have been reported on alcoholic extracts from C. ibuensis [9], C. digitata [33] and C. quadrangularis [34]. Stilbenes were the second most common class 
of polyphenolic compounds identified in the stems of $C$. trifoliata. Previously, resveratrol, piceatannol, and pallidol were isolated and characterized in ethanolic extracts from the stems of $C$. quadrangularis [8]. Stilbene glucosides have also been found in C. repens [35] and C. sicyoides [7].

In addition to previous reports of the phytochemical content of Cissus plants, their phylogeny also supports a metabolic profile characterized for a high content of flavonoids and stilbenes. For example, based on plastid markers, Cissus plants are genetically related with Vitis plants [36], the metabolomic profile of which showed overrepresentation of flavonoid and stilbene metabolites and their biosynthetic pathways [37]. Additionally, stilbene derivatives characterize and accumulate in the lignified stem tissue of Vitaceae plants [38].

\subsection{Antibacterial Activity}

The antibacterial activity of various extracts from the stems of $C$. quadrangularis has already been reported. The ethyl acetate, methanol and aqueous extracts showed inhibitory activity against the Gram-positive bacteria Bacillus subtilis, Bacillus cereus, S. aureus and Streptococcus species. In contrast, negative activity was found against the Gram-negative bacteria E. coli and P. aeruginosa [2]. Our study found null antibacterial activity against the fifteen bacteria tested. This may be explained because the antibacterial activity of $C$. quadrangularis was carried out by the agar well diffusion method. Additionally, the lowest concentration of extracts employed in the assays was $1000 \mu \mathrm{g} / \mathrm{mL}$ [2]. The highest concentration used in this study was $500 \mu \mathrm{g} / \mathrm{mL}$ in the micro-dilution broth method in 96-well microplates and extracts were considered inactive if the calculated MIC results were $>30 \mu \mathrm{g} / \mathrm{mL}$, according to recommendations of the National Committee for Clinical Laboratory Standards [25]. Thus, the results of the antibacterial activity analysis suggest that $C$. trifoliata extracts are inactive against bacteria although antibacterial properties against other strains or other antimicrobial activities cannot be excluded.

\subsection{Cytotoxic Activity}

The assessment of cytotoxicity of $C$. trifoliata extracts using MTS assay demonstrated activity against the six carcinoma cell lines exhibiting an $\mathrm{IC}_{50}$ values from 24 to $94 \mu \mathrm{g} / \mathrm{mL}$. The extracts from the stems of $C$. trifoliata present potent activities against liver and breast cancer cells. The hexane extract was able to inhibit the proliferation of liver and breast cancer cells at $24-30 \mu \mathrm{g} / \mathrm{mL}$, whereas the aqueous extract showed activity against breast cancer cells at $30 \mu \mathrm{g} / \mathrm{mL}$. According to the National Cancer Institute plant, extracts with an $\mathrm{IC}_{50} \leq 30 \mu \mathrm{g} / \mathrm{mL}$ possess good cytotoxic properties [26]. Previous reports in the literature demonstrated the cytotoxic activity of extracts from the stems of Cissus plants against cancer cell lines. The hexane and acetone extracts from $C$. quadrangularis showed cytotoxic activity against HepG2 and Hela cells ( $\mathrm{IC}_{50}$ from $43-200 \mu \mathrm{g} / \mathrm{mL}$ ). In another study, the ethyl acetate extract from C. sicyoides was cytotoxic for the HepG2 cells $\left(\mathrm{IC}_{50}\right.$ of $\left.50 \mu \mathrm{g} / \mathrm{mL}\right)$.

The cytotoxic or antiproliferative activity of $C$. trifoliata extracts may be mediated by their terpene, flavonoid and stilbene content. For example, stigmasterol showed cytotoxic activity against MCF7 cells $\left(\mathrm{IC}_{50} 14 \mu \mathrm{g} / \mathrm{mL}\right.$ ) [39]. $\beta$-Sitosterol also demonstrated cytotoxic activity against MCF7 (IC 50 $8 \mu \mathrm{g} / \mathrm{mL}$ ) [40] and Hep3B cells ( $\mathrm{IC}_{50} 25 \mu \mathrm{g} / \mathrm{mL}$ ) [41]. $\beta$-Sitosterol induces apoptosis mediated by caspase-8 activity [42] and by modulation of the estrogen receptor (ER), which inhibits the proliferation of sensitive cancer cells such as MCF7 [43]. Lupeol also possessed cytotoxicity activity against MCF7 (IC $5032 \mu \mathrm{g} / \mathrm{mL}$ ) and HepG2 cells ( $\mathrm{IC}_{50} 48 \mu \mathrm{g} / \mathrm{mL}$ ) [44]. Its mechanism of action was the induction of apoptosis through the mitochondrial cell death pathway and cell cycle arrest by inhibition of bcl-2 (B-cell lymphoma 2 protein) and CDKs (cyclin-dependent kinases) [45]. The polyphenols resveratrol, quercetin and kaempferol have been showed several anticancer mechanisms of action. For example, resveratrol induces cell-cycle arrest and acts as anti-estrogen in MCF7 cells ( $\mathrm{IC}_{50} 32 \mu \mathrm{g} / \mathrm{mL}$ ) [46]. Kaempferol also blocks the cell cycle and ER signaling acting. Doses of 50-100 $\mu \mathrm{M}$ decreased the cell viability in MCF7 and downregulated the expressions of cyclin proteins D1 and E, but increased p21 protein expression (p21 Cyclin-dependent kinase inhibitor) [47]. Quercetin showed similar mechanisms of action in 
MCF cells ( $\mathrm{IC}_{50} 50 \mu \mathrm{M} / \mathrm{mL}$ ), inhibited the proliferation and induced apoptosis by increasing caspase-3 expression [48]. Additionally, quercetin also possessed ER antagonism [49]. Together, these studies suggest synergistic activity of the bioactive compounds of the extracts of $C$. trifoliata against cancer cells.

Gross metabolic profiling has been previously useful to understand the bioactive content of medicinal plants, to compare it with taxonomically related studied plants and to infer or understand their bioactivity $[19,20]$. Accordingly, a metabolic profile high in terpenes, flavonoids and stilbenes in extracts from the stems of C. trifoliata was consistent with other studies of Cissus plants [8] and well characterized Vitaceae [37]. Moreover, the anti-tumor activity of $C$. sicyoides extracts in vivo has been attributed to $\beta$-sitosterol, quercetin, kaempferol and resveratrol [4]. Nonetheless, since a comparison with literature and databases was used for compound identification, to characterize at higher level of confidence, the inclusion of authentic standards is required [21]. Furthermore, since cytotoxic activity of the plant extracts was found against liver and breast cancer cells, it will be necessary to carry out a bio-assay guided study to isolate and characterize the bioactive compounds and to evaluate their mechanism of action in order to provide further understanding of the medicinal effects on this plant against tumors.

\section{Materials and Methods}

\subsection{Plant Material and Extraction}

C. trifoliata was collected and identified by a trained Biologist in Rayones, Nuevo León, Mexico (Latitude, $25.0167^{\circ}$, Longitude: $-100.05^{\circ}$, Altitude: $900 \mathrm{~m}$ ) on 10 October 2016. A voucher (027499) specimen was deposited in the Department of Botany of Universidad Autonóma de Nuevo León. The plant name has been checked in the website http://www.theplantlist.org. Dried and ground stems (756 g) were subjected to exhaustive extractions by maceration with hexane ( $4 \mathrm{~L}, 48 \mathrm{~h}), \mathrm{CHCl}_{3}-\mathrm{MeOH}$ (1:1) (9 L, 4 times, $24 \mathrm{~h}$ each), and distilled water $(4 \mathrm{~L}, 24 \mathrm{~h})$. Solvents used were chloroform $\left(\mathrm{CHCl}_{3}\right)$ purity $98.8 \%$, methanol $(\mathrm{MeOH})$ purity $99.9 \%$, and hexane purity $98.99 \%$ (Baker, Phillipsburg, New Jersey, USA). The organic extracts were filtered and concentrated using a rotary evaporator at $40{ }^{\circ} \mathrm{C}$ (V300, Buchi, Flawil, Switzerland), and the aqueous extract was lyophilized. The extract yield was $3.5 \mathrm{~g}(0.423 \%)$ for hexane, $24 . \mathrm{g}(3.201 \%)$ for $\mathrm{CHCl}_{3}-\mathrm{MeOH}$, and $8.2 \mathrm{~g}(1.084 \%)$ for aqueous. The dried extracts were kept at $4{ }^{\circ} \mathrm{C}$ until used.

\subsection{GC-MS Analysis}

The hexane extract was examined by GC-MS Agilent GC 6890, MSD 5973N (Agilent Technologies, Santa Clara, CA, USA) to determine its chemical composition. The analysis was conducted with the column HP-5MS $(30 \mathrm{~mm} \times 0.25 \mathrm{~mm} \times 0.25 \mu \mathrm{m})$. The carrier gas was helium with a gas flow rate of $1 \mathrm{~mL} / \mathrm{min}$ and a linear velocity of $37 \mathrm{~cm} / \mathrm{s}$. The injector temperature was set at $270^{\circ} \mathrm{C}$. The initial oven temperature was $70{ }^{\circ} \mathrm{C}$ and increased to $200^{\circ} \mathrm{C}$ at $10{ }^{\circ} \mathrm{C} / \mathrm{min}, 200^{\circ} \mathrm{C}$ to $310^{\circ} \mathrm{C}$ at $10{ }^{\circ} \mathrm{C} / \mathrm{min}$ and the final temperature was held for $5 \mathrm{~min}$ at $310^{\circ} \mathrm{C}$. The mass spectrometer was operated in the electron ionization mode at $70 \mathrm{eV}$ and electron multiplier voltage at $1859 \mathrm{~V}$. The retention index of compounds was recorded with standard n-hydrocarbon calibration mixture (C10-C40, Honeywell Fluka, Germany) using 2.64 AMDIS software. The compounds were identified by comparison of spectral data, fragmentation patter, and Kovats retention index with referent compounds in the NIST 17 database [23].

\subsection{UPLC-QTOF-MS Analysis}

Samples were diluted in LCMS grade $\mathrm{MeOH}(50 \%)$ (Fisher Scientific, Ottawa, Canada), filtered using Supelco (54145-U) Iso-disc, N-4-2 nylon, $4 \mathrm{~mm} \times 0.2 \mu \mathrm{m}$ filters (Fisher Scientific, Ottawa, Canada), and transferred to a high-recovery amber vial (Agilent Technologies, Santa Clara, CA, USA). Reverse-phase liquid chromatography was performed using an Agilent 1290 Infinity Ultra High-Performance Liquid The chromatography system (UHPLC) and the column ZORBAX C18, $2.1 \times$ 
$50 \mathrm{~mm}, 1.8 \mu \mathrm{m}$ (Agilent Technologies, Santa Clara, CA, USA) maintained at an isothermal temperature of $38^{\circ} \mathrm{C}$. The mobile phase was delivered by a binary pump at flow rate of $0.250 \mathrm{~mL} / \mathrm{min}$ in a gradient elution using two mobile phases: LCMS grade water $+0.1 \% v / v$ formic acid (solvent A) (Fisher Scientific, Ottawa, Canada), and LCMS grade MeOH $+0.1 \% v / v$ formic acid (solvent B) (Fisher Scientific, Ottawa, Canada), with the following gradient conditions: $0-6 \mathrm{~min}, 100 \%$ solvent $\mathrm{B}$; held at $100 \% 10 \mathrm{~min}, 100 \%$ B; $11 \mathrm{~min}, 30 \% \mathrm{~B}$. The autosampler was set with an injection volume of $5 \mu \mathrm{L}$. The flush port was set to clean injection needle for 30s intervals. A mass spectrometric analysis was performed using an Agilent 6530 Quadrupole Time of Flight (QTOF) LCMS with an electrospray ionization (ESI) source (Agilent Technologies, Santa Clara, CA, USA). A mass spectrometry analysis was conducted in positive ion mode, set for a detection of mass-to-charge ratio $(\mathrm{m} / \mathrm{z})$ of 100 to 1000 . The nebulizer pressure was set at $35 \mathrm{psi}$ with a surrounding sheath gas temperature of $350^{\circ} \mathrm{C}$ and a gas flow rate of $11 \mathrm{~L} / \mathrm{min}$. The drying gas temperature was set at $300{ }^{\circ} \mathrm{C}$ with a flow rate of $10 \mathrm{~L} / \mathrm{min}$. Default settings were used to set voltage gradient for the nozzle at $1000 \mathrm{~V}$, skimmer at $65 \mathrm{~V}$, capillary (VCap) at $3500 \mathrm{~V}$, and fragmentor at 175 V. A record of LCMS data was taken using a MassHunter 6200 series TOF/6500 series Q-TOF B.05.01. MS acquisition was performed with three replicate injections to allow column conditioning and to examine reproducibility. Mass spectra were processed using the METLIN Database add-in for Agilent MassHunter Qualitative Analysis B.06.00. To putative compound identification, the correct elemental composition was generated using the accurate $\mathrm{m} / \mathrm{z}$ and the molecular formula generation software (Agilent Technologies, Santa Clara, CA, USA) [24]. Data were queried against the online METLIN [24] and HMDB [50] databases.

\subsection{Antibacterial Activity}

The tested bacteria include seven bacteria from the ATCC (American Type Culture Collection, Manassas, VA, USA) and nine resistant strains isolated in the University Hospital of the Universidad Autonoma de Nuevo León (Monterrey, Nuevo León, Mexico). The bacteria from the ATCC include three gram-positive bacteria; Staphylococcus aureus (ATCC, 29213), Staphylococcus epidermidis (ATCC,14990) and Enterococcus faecium (ATCC, 2127) and four Gram-negative bacteria, Acinetobacter baumanni (ATCC, 13883), Escherichia coli (ATCC, 25922), Pseudomonas aeruginosa (ATCC, 27853), and Klebsiella pneumoniae (ATCC, 19606). The drug-resistant Gram-positive bacteria were methicillin-resistant S. aureus (14-2095), linezolid-resistant S. epidermidis (14-583), and vancomycin-resistant E. faecium (10-984). The drug resistant Gram-negative bacteria were carbapenem-resistant $A$. baumannii (12-666), extended spectrum $\beta$-lactamase (ESBL) E. coli (14-2081), carbapenem-resistant P. aeruginosa (13-1391), oxacillin-resistant (OXA-48) K. pneumoniae (17-1692), and New Delhi metallo- $\beta$-lactamase 1 (NDM-1+) K. pneumoniae (14-3335). The minimum inhibitory concentrations (MIC) of the extracts and the positive control levofloxacin were determined in duplicate by the micro-dilution broth method in 96-well microplates [51]. The aqueous extract was dissolved in distilled water, while organic extracts and levofloxacin were dissolved in dimethyl sulfoxide (DMSO) (Baker, Phillipsburg, New Jersey, USA). The solutions were then diluted in Mueller-Hinton broth (Difco, Detroit, MI, USA) in order to achieve concentrations ranging from 500, 250, 125, 62.5, 31.2, 15.6 and $7.8 \mu \mathrm{g} / \mathrm{mL}$ for extracts and 200, 100, 50, 25, $12.5,6.25$ and $3.12 \mu \mathrm{g} / \mathrm{mL}$ for levofloxacin according to the literature [25]. The range of concentrations used for DMSO was from $6 \%$ to $0.09 \%(v / v)$ and this solution was used as a negative control. The strains were inoculated on plates prepared with $5 \%$ blood agar and cultured for $24 \mathrm{~h}$ at $37^{\circ} \mathrm{C}$. The strains of P. aeruginosa and S. epidermidis were incubated for $48 \mathrm{~h}$ at $37^{\circ} \mathrm{C}$. One to three colonies from the blood agar plate were selected and transferred to a tube containing $5 \mathrm{~mL}$ of sterile saline solution. The suspension was adjusted to 0.5 MacFarland's standard $\left(1.5 \times 10^{8} \mathrm{CFU}\right)$. Then, $10 \mu \mathrm{L}$ of this suspension was transferred into $11 \mathrm{~mL}$ Mueller Hinton broth to achieve $1.5 \times 10^{5} \mathrm{CFU} / \mathrm{mL}$. One hundred microliter of Mueller Hinton broth was added into each well of the 96-well plate. Further, $100 \mu \mathrm{L}$ of each solution to be tested was added to the wells of line A. Then, a serial dilution (1:2) was carried out through the plate until line G. Then, $100 \mu \mathrm{L}$ of bacterial suspension $\left(1.5 \times 10^{8} \mathrm{CFU}\right)$ was added to all the wells except line $\mathrm{H}$ which was the sterility control. Plates were incubated at $37^{\circ} \mathrm{C}$ for 24 or $48 \mathrm{~h}$ depending on the 
bacteria. After the incubation, the turbidity or bottom deposition was visually evaluated to determine the microorganism viability. The MIC values were determined as the lowest concentration able to inhibit the microorganism growth. According with the National Committee for Clinical Laboratory Standards, extracts with a MIC value $\geq 30 \mu \mathrm{g} / \mathrm{mL}$ were considered negative for antibacterial activity [25].

\subsection{Cytotoxic Activity}

The cytotoxic activity was investigated on human cancer cell lines PC3 (prostate cells), Hep3B (liver cells), HepG2 (liver cells), MCF7 (breast cells), A549 (lung cells) and HeLa (cervical cells) obtained from the ATCC. PC3 cells were cultured in medium RPMI-1640 (Sigma-Aldrich, St. Louis, MO, USA), and the other cells in medium DMEM (Sigma-Aldrich, St. Louis, MO, USA), supplemented with fetal bovine serum $10 \%$ (Gibco, Gaithersburg, MD, USA), $2 \mathrm{mM}$ glutamine, and incubated at $37^{\circ} \mathrm{C}$ in an atmosphere of $5 \% \mathrm{CO}_{2}$. Cell passages were maintained in T75 flasks and passages 4-15 were used for the experiments. Prior to treatments, cells were dissociated with TrypLE Express (Gibco, Gaithersburg, MD, USA), seeded at approximately 5000 cells per well in the 96-well plate and allowed to adhere overnight. Cell count and viability were determined using Neubauer hemocytometer and trypan blue staining. The concentrations used for the extracts and for the positive control paclitaxel were 100, 10, 1, $0.1,0.001 \mu \mathrm{g} / \mathrm{mL}$ for a dose/response with an exposition of $72 \mathrm{~h}$, according to recommendations [26]. Thus, concentrations assayed allowed the determination of the half maximal inhibitory concentration $\left(\mathrm{IC}_{50}\right)$ by a regression analysis with the statistical program Prism 5 . The guideline used as reference was the National Cancer Institute, which considers cytotoxic the extracts with an $\mathrm{IC}_{50} \leq 30 \mu \mathrm{g} / \mathrm{mL}$ [26]. The proliferation was determined using the CellTiter 96 Assay kit (Promega, Madison, WI, USA), following the manufacturer's protocol. The absorbance was quantified at $450 \mathrm{~nm}$ using an ELISA reader. The experiments were performed in triplicate in three independent experiments.

\section{Conclusions}

This is the first report of the qualitative metabolic profile of $C$. trifoliata and its antibacterial and cytotoxic evaluation. The extracts of $C$. trifoliata stems were rich in terpenes, flavonoids and stilbenes. The hexane and aqueous extracts showed cytotoxic activity in vitro against Hep3B, HepG2 and MCF7 cancer cells. Overall, this study suggests that the cytotoxic activity can be partially explained by their metabolic profile rich in bioactive compounds. This work provides evidence of the anticancer effects of this plant used in the traditional medicine and justify further study of the antitumor activities $C$. trifoliata.

Author Contributions: L.F.M.-L. prepared the extracts, established the chromatographic conditions, analyzed the results and wrote the manuscript. L.G.-M. and J.N.S.-C. realized the cytotoxic assays. L.F.M.-L. and E.G.-G. conducted the antibacterial assays. L.F.M.-L., M.Y.R., M.Á.R.-C. performed the UPLC-QTOF-MS analysis. L.A. performed the GC-MS experiments. M.d.R.C.-C. contributed with the design and supervised the development of this project. All authors contributed to a critical reading of the manuscript. All authors have read and agreed to the published version of the manuscript.

Funding: This research did not receive any specific grant from funding agencies in the public, commercial, or not-for-profit sectors.

Acknowledgments: The manuscript was taken in part from the PhD thesis of LFML. LFML thanks CONACYT-Mexico for the scholarship (210600) to carry out his PhD studies. We thank the biologist Mauricio Gonzalez-Ferrara for the identification and collection of the plant. We thank Sam Williams for improving the grammar and spelling of manuscript.

Conflicts of Interest: The authors declare no conflict of interest.

\section{Abbreviations}
A431 Human epidermoid carcinoma in cell line
ATCC American Type Culture Collection
$\mathrm{Bcl} 2 \quad$ B-cell lymphoma 2
CaCo-2 Human colon caucasian colon adenocarcinoma 


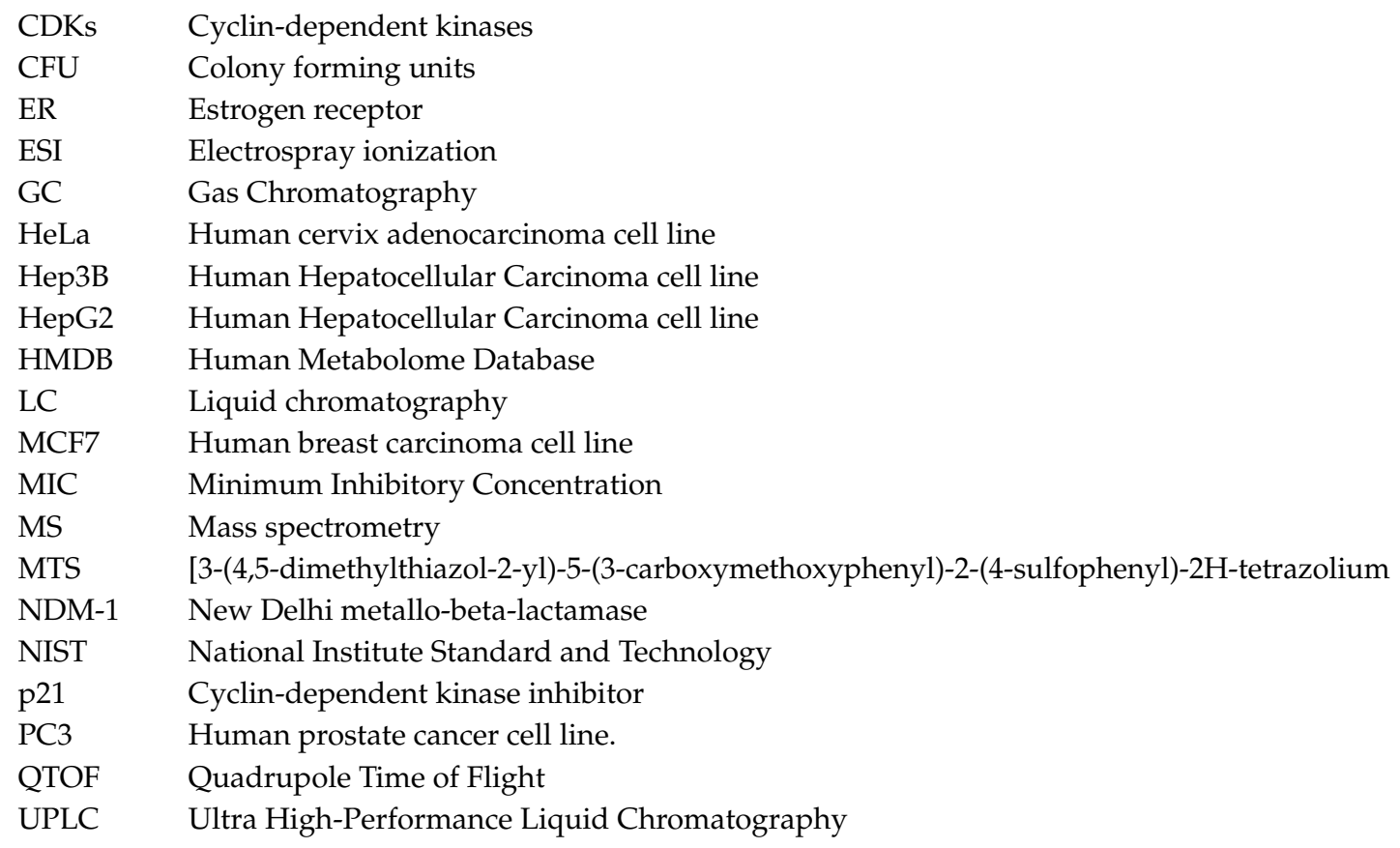

\section{References}

1. Banu, J. Medicinal properties of plants from the genus Cissus: A review. J. Med. Plant. Res. 2012, 6, 3080-3086.

2. Chidambara, M.; Vanitha, A.; Mahadeva, M.; Ravishankar, G. Antioxidant and antimicrobial activity of Cissus quadrangularis L. J. Med Food. 2003, 6, 99-105. [CrossRef] [PubMed]

3. Bhujade, A.; Talmale, S.; Kumar, N.; Gupta, G.; Reddanna, P.; Patil, M. Evaluation of Cissus quadrangularis extracts as an inhibitor of COX, 5-LOX, and proinflammatory mediators. J. Ethnopharmacol. 2012, 141, 989-996. [CrossRef] [PubMed]

4. Lucena, F.; Almeida, E.; Aguiar, J.; Silva, T.; Souza, V.; Nascimento, S. Cytotoxic, antitumor and leukocyte migration activities of resveratrol and sitosterol present in the hidroalcoholic extract of Cissus sicyoides L., Vitaceae, leaves. Rev. Bras. de Farmacogn. 2010, 20, 729-733. [CrossRef]

5. Beltrame, F.L.; Sartoretto, J.L.; Bazotte, R.B.; Cuman, R.N.; Cortez, D.; Fernandes, L.C.; Tchaikovski, O. Phytochemical study and evaluation of the antidiabetic potential of Cissus sicyoides L. (Vitaceae). Braz. Arch. Biol. Technol. 2001, 24, 783-785.

6. Pathomwichaiwat, T.; Ochareon, P.; Soonthornchareonnon, N.; Ali, Z.; Khan, I.A.; Prathanturarug, S. Alkaline phosphatase activity-guided isolation of active compounds and new dammarane-type triterpenes from Cissus quadrangularis hexane extract. J. Ethnopharmacol. 2015, 160, 52-60. [CrossRef]

7. Xu, F.; Matsuda, H.; Hata, H.; Sugawara, K.; Nakamura, S.; Yoshikawa, M. Structures of new flavonoids and benzofuran-type stilbene and degranulation inhibitors of rat basophilic leukemia cells from the Brazilian herbal medicine Cissus sicyoides. Chem. Pharm. Bull. 2009, 57, 1089-1095. [CrossRef]

8. Adesanya, S.A.; Nia, R.; Martin, M.; Boukamcha, N.; Montagnac, A.; Païs, M. Stilbene derivatives from Cissus quadrangularis. J. Nat. Prod. 1999, 62, 1694-1695. [CrossRef]

9. Ahmadu, A.; Onanuga, A.; Aquino, R. Flavonoid glycosides from the leaves of Cissus ibuensis hook (vitaceae). Afr. J. Tradi. Complement. Altern. Med. 2010, 7, 225-230. [CrossRef] [PubMed]

10. Heinrich, M.; Ankli, A.; Frei, B.; Weimann, C.; Sticher, O. Medicinal plants in Mexico: Healers' consensus and cultural importance. Soc. Sci. Med. 1998, 47, 1859-1871. [CrossRef]

11. Alvarado, V.; Moreno, L. Las Plantas útiles de Nuevo León. De la Lechuguilla a las Biopelículas Vegetales; Universidad Autónoma de Nuevo León: Monterrey, Nuevo León, Mexico, 2010; Volume 1, p. 650.

12. Perez, R.; Pérez, S.; Perez, C.; Zavala, M. Anti-inflammatory activity of Cissus trifoliata. Fitotherapy 1993, 64, 103-107.

13. Kashikar, N.; George, I. Antibacterial activity of Cissus quadrangularis Linn. Indian J. Pharm. Sci. 2006, 68, 245-247. 
14. Selvan, A.T.; Yezdhani, R.; Subramanian, N.S.; Devi, M.R.; Prasad, B.S.G.; Kumar, S.; Parimala, S. Antimicrobial activity of methanolic extract of Cissus pallida. Int. J. Pharmacog. 2014, 1, 592-595.

15. Bhujade, A.; Gupta, G.; Talmale, S.; Das, S.; Patil, M. Induction of apoptosis in A431 skin cancer cells by Cissus quadrangularis Linn stem extract by altering Bax-Bcl-2 ratio, release of cytochrome c from mitochondria and PARP cleavage. Food. Funct. 2013, 4, 338-346. [CrossRef]

16. Opoku, A.; Geheeb-Keller, M.; Lin, J.; Terblanche, S.; Hutchings, A.; Chuturgoon, A.; Pillay, D. Preliminary screening of some traditional Zulu medicinal plants for antineoplastic activities versus the HepG2 cell line. Phytother. Res. 2000, 14, 534-537. [CrossRef]

17. Sáenz, M.; Garcia, M.; Quilez, A.; Ahumada, M. Cytotoxic activity of Agave intermixta L. (Agavaceae) and Cissus sicyoides L. (Vitaceae). Phytother. Res. 2000, 14, 552-554. [CrossRef]

18. Line-Edwige, M.; Raymond, F.G.; François, E.; Edouard, N. Antiproliferative effect of alcoholic extracts of some Gabonese medicinal plants on human colonic cancer cells. Afr. J. Tradit. Complement. Altern. Med. 2009, 6, 112-117. [CrossRef]

19. Graziani, V.; Scognamiglio, M.; Belli, V.; Esposito, A.; Chambery, A.; Panella, M.; Ciardello, F. Metabolomic approach for a rapid identification of natural products with cytotoxic activity against human colorectal cancer cells. Sci. Rep. 2018, 8, 5309. [CrossRef]

20. Farag, M.; Weigend, M.; Luebert, F.; Brokamp, G.; Wessjohann, L. Phytochemical, phylogenetic, and anti-inflammatory evaluation of 43 Urtica accessions (stinging nettle) based on UPLC-Q-TOF-MS metabolomic profiles. Phytochemistry 2013, 96, 170-183. [CrossRef]

21. Sumner, L.; Amberg, A.; Barrett, D.; Beale, M.; Beger, R.; Daykin, C.; Viant, M. Proposed minimum reporting standards for chemical analysis. Metabolomics 2007, 3, 211-221. [CrossRef]

22. Dettmer, K.; Aronov, P.; Hammock, B. Mass spectrometry-based metabolomics. Mass. Spectrom. Rev. 2007, 26, 51-78. [CrossRef] [PubMed]

23. Vinaixa, M.; Schymanski, E.L.; Neumann, S.; Navarro, M.; Salek, R.M.; Yanes, O. Mass spectral databases for LC/MS-and GC/MS-based metabolomics. Trac. Trend. Anal. Chem. 2016, 78, 23-35. [CrossRef]

24. Sana, T.; Roark, J.; Li, X.; Waddell, K.; Fischer, S. Molecular formula and METLIN Personal Metabolite Database matching applied to the identification of compounds generated by LC/TOF-MS. J. Biomol. Tech. 2008, 19, 258-266. [PubMed]

25. Murray, P.R.; Baron, E.J.; Pfaller, M.A.; Tenover, F.C.; Myolken, R.H. National Committee for Clinical Laboratory Standards. Antibacterial Susceptibility Tests: Dilution and Disk Diffusion Methods. In Manual of Clinical Microbiology; Springer: Boston, MA, USA, 1999; pp. 1526-1543.

26. Grever, M.R.; Schepartz, S.A.; Chabner, B.A. The National Cancer Institute: Cancer drug discovery and development program. In Seminars in Oncology; National Center for Biotechnology Information: Bethesda, MD, USA, 1992; pp. 622-638.

27. Halket, J.; Waterman, D.; Przyborowska, A.; Patel, R.; Fraser, P.; Bramleym, P. Chemical derivatization and mass spectral libraries in metabolic profiling by GC/MS and LC/MS/MS. J. Exp. Bot. 2005, 56, 219-243. [CrossRef]

28. Heredia-Guerrero, J.A.; Benítez, J.J.; Domínguez, E.; Bayer, I.S.; Cingolani, R.; Athanassiou, A.; Heredia, A. Infrared and Raman spectroscopic features of plant cuticles: A review. Front. Plant. Sci. 2014, 5, 305. [CrossRef]

29. Aggarwal, B.; Ali, M.; Singla, R. Isolation and Characterization of Phytoconstituents from the Stems of Ichnocarpus frutescens. Chin. J. Nat. Med. 2010, 8401-8404. [CrossRef]

30. Vishnuthari, N.; Sripathi, S.K. GC-MS Analysis of Hexane Extract of Stems and Roots of the Ethnomedicinal Plant Cissus quadrangularis Linn. J. Chem. Bio. Phy. Sci. 2015, 5, 3954-3963.

31. Kumar, T.S.; Anandan, A.; Jegadeesan, M. Identification of chemical compounds in Cissus quadrangularis L. Variant I of different samples using GC-MS analysis. Arch. Appl. Sci. Res. 2012, 4, 1782-1787.

32. Shah, U.; Patel, S.M.; Patel, P.H.; Hingorani, L.; Jadhav, R.B. Development and Validation of a Simple Isocratic HPLC Method for Simultaneous Estimation of Phytosterols in Cissus quadrangularis. Indian. J. Pharm. Sci. 2010, 72, 753-758.

33. Al-Said, M.; Khalifa, A.; Al-Azizi, M. Flavonoids from Cissus digitata. Int. J. Pharm. 1991, 29, $281-283$. [CrossRef] 
34. Vijayalakshmi, A.; Kumar, P.; Sakthi, S.; Meenaxshi, C. In vitro antioxidant and anticancer activity of flavonoid fraction from the aerial parts of Cissus quadrangularis linn against human breast carcinoma cell lines. J. Chem. 2013, 150675. [CrossRef]

35. Wang, Y.-H.; Zhang, Z.-K.; He, H.-P.; Wang, J.-S.; Zhou, H.; Ding, M.; Hao, X.-J. Stilbene C-glucosides from Cissus repens. J. Asian. Nat. Prod. Res. 2007, 9, 631-636. [CrossRef] [PubMed]

36. Tröndle, D.; Schröder, S.; Kassemeyer, H.H.; Kiefer, C.; Koch, M.A.; Nick, P. Molecular phylogeny of the genus Vitis (Vitaceae) based on plastid markers. Am. J. Bot. 2010, 97, 1168-1178. [CrossRef]

37. Billet, K.; Houillé, B.; de Bernonville, T.D.; Besseau, S.; Oudin, A.; Courdavault, V.; Delanoue, G.; Guérin, L.; Clastre, M.; Giglioli-Guivarc'h, N. Field-based metabolomics of vitis vinifera 1. stems provides new insights for genotype discrimination and polyphenol metabolism structuring. Front. Plant. Sci. 2018, 21, 798. [CrossRef]

38. Kiselev, K.; Aleynova, O.; Grigorchuk, V.; Dubrovina, A.S. Stilbene accumulation and expression of stilbene biosynthesis pathway genes in wild grapevine Vitis amurensis Rupr. Planta 2017, 245, 151-159. [CrossRef]

39. Shan, L.Y.; Thing, T.C.; Ping, T.S.; Awang, K.; Hashim, N.M.; Nafiah, M.A.; Ahmad, K. Cytotoxic, antibacterial and antioxidant activity of triterpenoids from Kopsia singapurensis Ridl. J. Chem. Pharm. Res. 2014, 6, 815-822.

40. Awad, A.B.; Barta, S.L.; Fink, C.S.; Bradford, P.G. $\beta$-Sitosterol enhances tamoxifen effectiveness on breast cancer cells by affecting ceramide metabolism. Mol. Nutr. Food. Res. 2008, 252, 419-426. [CrossRef]

41. Samita, F.; Ochieng, C.O.; Owuor, P.O.; Manguro, L.O.A.; Midiwo, J.O. Isolation of a new $\beta$-carboline alkaloid from aerial parts of Triclisia sacleuxii and its antibacterial and cytotoxicity effects. Nat. Prod. Res. 2017, 31, 529-536. [CrossRef]

42. Awad, A.; Chinnam, M.; Fink, C.; Bradford, P. $\beta$-Sitosterol activates Fas signaling in human breast cancer cells. Phytomedicine 2007, 14, 747-754. [CrossRef]

43. Ju, Y.H.; Clausen, L.M.; Allred, K.F.; Almada, A.L.; Helferich, W.G. $\beta$-sitosterol, $\beta$-sitosterol glucoside, and a mixture of $\beta$-sitosterol and $\beta$-sitosterol glucoside modulate the growth of estrogen-responsive breast cancer cells in vitro and in ovariectomized athymic mice. J. Nutr. 2004, 134, 1145-1151. [CrossRef] [PubMed]

44. Tahsin, T.; Wansi, J.D.; Al-Groshi, A.; Evans, A.; Nahar, L.; Martin, C.; Sarker, S.D. Cytotoxic Properties of the Stem Bark of Citrus reticulata Blanco (Rutaceae). Phytother. Res. 2017, 31, 1215-1219. [CrossRef] [PubMed]

45. Prasad, S.; Nigam, N.; Kalra, N.; Shukla, Y. Regulation of signaling pathways involved in lupeol induced inhibition of proliferation and induction of apoptosis in human prostate cancer cells. Mol. Carcinog. 2008, 47, 916-924. [CrossRef]

46. El-Mowafy, A.M.; Alkhalaf, M. Resveratrol activates adenylyl-cyclase in human breast cancer cells: A novel, estrogen receptor-independent cytostatic mechanism. Carcinogenesis 2003, 24, 869-873. [CrossRef]

47. Kim, S.H.; Hwang, K.A.; Choi, K.C. Treatment with kaempferol suppresses breast cancer cell growth caused by estrogen and triclosan in cellular and xenograft breast cancer models. J. Nutr. Biochem. 2016, 2, 70-82. [CrossRef] [PubMed]

48. Khorsandi, L.; Orazizadeh, M.; Niazvand, F.; Abbaspour, M.R.; Mansouri, E.; Khodadadi, A. Quercetin induces apoptosis and necroptosis in MCF-7 breast cancer cells. Bratisl. Lek. Listy. 2017, 118, 123-128. [CrossRef] [PubMed]

49. Ranganathan, S.; Halagowder, D.; Sivasithambaram, N.D. Quercetin suppresses twist to induce apoptosis in MCF-7 breast cancer cells. PLoS ONE 2015, 10, e0141370. [CrossRef] [PubMed]

50. Wishart, D.S.; Feunang, Y.D.; Marcu, A.; Guo, A.C.; Liang, K.; Vázquez-Fresno, R.; Sajed, T.; Johnson, D.; Li, C.; Karu, N. HMDB 4.0: The human metabolome database for 2018. Nucleic. Acids. Res. 2017, 4, D608-D617. [CrossRef]

51. Zgoda, J.; Porter, J. A convenient microdilution method for screening natural products against bacteria and fungi. Pharm. Biol. 2001, 39, 221-225. [CrossRef]

(C) 2020 by the authors. Licensee MDPI, Basel, Switzerland. This article is an open access article distributed under the terms and conditions of the Creative Commons Attribution (CC BY) license (http://creativecommons.org/licenses/by/4.0/). 